\title{
The Concept of E-Voting Mechanism Based on Law of General Election and Information Security
}

\author{
Bayu Sujadmiko ; Iskardo P. Panggar ${ }^{\star \star}$; Ade Sofyansah ${ }^{\star \star \star}$; \\ Intan Fitri Meutia \\ *International Law Department, Law Faculty, Universitas \\ Lampung-Indonesia \\ bayu.sujadmiko@fh.unila.ac.id

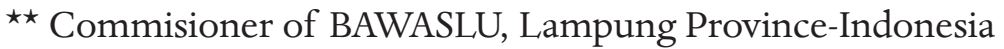 \\ idosatu@gmail.com \\ ${ }^{\star \star \star}$ District Attorney, Bandar Lampung-Indonesia \\ adekensofyansah@gmail.com \\ $\star \star \star \star$ Public Administration Department, Universitas Lampung- \\ Indonesia \\ intan.fitri@fisip.unila.ac.id
}

\begin{abstract}
The development of technology has made transformation in the world; one of them is the implementation of e-voting systems in general elections. This research aims to dig deeper into the utilization of e voting in Indonesia's general election according to the Law on General Election, and research on the e-voting safety aspect in Indonesia's general election with the Law on ITE, government regulation on One Data Indonesia, and the Bill of Personal Data Protection Law. The research method is normative, which is delivered with an analytic-descriptive method. The results show that Indonesia has arranged elections with e-voting mechanisms for multiples of times, for example, in Jembrana Regency. Based on the General Election Law, e voting could be implemented in Indonesia. However, there
\end{abstract}


are still considerations in terms of technology and preparation that should prevent unwanted burden. There needs to be a regulation for voters' data management to prevent violations against human rights. Data management must pay attention to safety aspects guided by the Law on ITE, government regulation on One Data Indonesia, and the Bill of Personal Data Protection Law.

Keywords: Democracy; E-Voting; Security.

\section{A. Introduction}

Etymologically, democracy comes from the words demos and kratos, which means people and government. It can be said that democracy is a government that comes from the people, by the people and for the people. ${ }^{1}$ In relation, democracy and law are a political system that is very close to each other. ${ }^{2}$ Democracy will not be adequately built if there is no law, so the law will be an elitist and repressive rule without a democratic political system. ${ }^{3} \mathrm{E}$-voting exists to solve the problem of boundaries that exist in the election mechanism. This e-voting aims to reach all participating citizens. The idea of e-voting is strongly influenced by the magnitude of the transformation of computer technology in the world. The transformation of conventional elections to E-voting in a developing country has experienced more significant increases than a country that has had stable democratic conditions. ${ }^{4}$ The development of e-voting is useful for supporting and improving the existence of a national electoral climate. Therefore, it can be useful for increasing participation in elections. ${ }^{5}$ E-voting exists to solve

1 Ziga Vodovnik, "Lost In Translation: The Original Meaning Of Democracy”, Teorija In Praksa, Let. 54, No. 1, 2017, p. 43.

2 Muntoha, "Demokrasi dan Negara Hukum" (Democracy and the State of Law), Jurnal Hukum, No. 3, Vol. 16, 2009, p. 279.

3 Moh. Mahfud M.D., Hukum dan Pilar-Pilar Demokrasi (Law and the Pillars of Democracy). Gama Media Offset, Yogjakarta, 1999.

4 R. Michael Alvarez, Ines Levin, Julia Pomares and Marcelo Leiras, "Voting Made Safe and Easy: The Impact of Evoting on Citizen Perceptions", Journal Political Science Research and Methods, 1, p. 117137 doi:10.1017/ psrm.2013.2.

5 Akos Cserny, András Nemeslaki, “The Challenges of E-voting”, Journal: Vieśoji Politika Ir Administravimas, Vol. 17, No.4, 2018, 497-509, https:// 
the problem of boundaries that exist in the election mechanism. This e-voting aims to reach all participating citizens. The idea of e-voting is strongly influenced by the magnitude of the transformation of computer technology in the world. ${ }^{6}$

Democratization in a law country is in the form of general election. ${ }^{7}$ Elections have at least two functions; the first is the procedure of converting voters' votes into seats for state administrators, the second is an instrument used as creating a democratic political system. ${ }^{8}$ A strict election will determine the extent of the legitimacy of the community in implementing public authority. ${ }^{9}$ In its development general elections in the world began to move from conventional systems, towards more modern systems using machines that are expected to be able to prevent fraud and other problems. ${ }^{10}$ Some countries that have implemented e-voting mechanisms in general elections in their countries include Brazil, India, Spain, Panama, Costa Rica, England, Argentina, Italy, Australia and Belgium. ${ }^{11}$

Transparent and safe approach must be taken to establish an efficient and effective electronic vote ${ }^{12}$ E-voting in Jordan for instance;

www.ceeol.com/search/article-detail?id=731501.

6 Anisaara Nadaph, Rakhi Bondre, Ashmita, dkk, "An Implementation of Secure Online Voting System", International Journal of Engineering Research and General Science, Volume 3, Issue 2, 2015, www.ijergs.org.

7 Sarbaini, "Demokratisasi dan Kebebasan Memilih Warga Negara Dalam Pemilihan Umum" (Democratisation and the Citizens' Freedom to Vote in General Election), Jurnal Inovatif, Vol. VIII, No. I, 2015, p. 107.

8 Ramlan Surbakti, Sistem Pemilu di Indonesia: Antara Proporsional dan Mayoritarian (The Election System in Indonesia: Between Proportional and Majoritarian), P3DI Setjen DPR Republik Indonesia dan AzzaGrafika, Jakarta, 2015.

9 Waldemar Wojtasik, "Functions Of Elections In Democratic Systems", Political Preferences, No. 4, 2013, p. 27.

10 https: / /www.cnnindonesia.com/internasional/20161108135120-134171169 / pemilu-as-pakai-mesin-canggih-sulit-dicurangi.

11 Sanjay Kumar, EktaWalia, "Analysis Of Electronic Voting System In Various Countries", International Journal on Computer Science and Engineering (IJCSE), Vol. 3, No. 5, 2011, p. 1826-1828.

12 Pavel Tarasov and Hitesh Tewari, “The Future Of E-Voting”, IADIS International Journal on Computer Science and Information Systems, Vol. 12, No. 2, p. 148-165. 
is influenced by several factors such as; public trust in government, attitudes, and perceptions of the usefulness and complexity of society. ${ }^{13}$

In his prediction, Rudiantara as the Minister of Communication and Information for the 2014-2019 period stated that the application of electronic elections (e-voting) could already be applied in the elections in 2024, provided that in terms of access and the system, there needed to be certainty. ${ }^{14}$ In Indonesia alone the use of machines in the general election has been implemented in several regions, one of which applies is 54 villages of Jembarana Regency. ${ }^{15}$ Judicially, the Constitutional Court's Decision has legitimized the election of 54 Hamlet Heads in Jembarana Regency through Decision of the Constitutional Court Number 147/PUU-VII/ 2009.

In the decision given by the Constitutional Court, it was said that the application of e-voting is in contradiction with Article 88 of Law No. 32/2004 on Regional Government could be approved with the note that the principle of direct, clean, honest and fair must underlie its implementation. ${ }^{16}$ With this decision also, the obstacles contained in Article 353 of Law No. $7 / 2017$ on General Elections, are no longer a juridical issue in the effort to use e-votingin Indonesia. The problem, as well as the challenge, is related to the implementation of e-voting in Article 85 of Law No. 10/2016 on the Regional Government must consider the readiness of the terms of infrastruc-

13 Mohammad Kamel Alomari, "E-Voting Adoption in A Developing Country”, Journal Transforming Government: People, Process and Policy, Vol. 10, No. 4, p. 526-547. https: / / doi.org/10.1108/TG-11-2015-0046.

14 https: / / www.republika.co.id/berita/nasional/politik/19/05/09/ pr7jdk428-menkominfo-evoting-bisa-diterapkan-pada-pilkada-2024.

15 https://www.bp.t.go.id/teknologi-informasi-energi-dan-material/1745-evoting-pilkades-jembrana-sebuah-miniatur-pemilukada.

16 Made Leita Anistiawati, "Implementasi Kebijakan Penerapan Elektronik Voting (E-Voting) dalam Pemilihan Kepala Desa (Studi Kasus: Pemilihan Kepala Desa di Desa Mendoyo Dangin Tukad, Kecamatan Mendoyo, Kabupaten Jembrana)" (Implementation of the Policy on Electronic Voting (E-Voting) in the Eelection of Head of Village (Case Study: the Election of Head of Village in Mendoyo Dangin Tukad Village, Mendoyo Subdistrict, Jembrana District)), Jurnal Ilmu Administrasi Negara, Vol. 1, No. 2, 2014, p. 7. 
ture that is safe and accountable and the readiness of the community based on the principle of efficiency and ease. ${ }^{17} \mathrm{E}$-voting can be a tool to increase public trust in national/regional elections. However, this could be a miscarry on political participation if the mechanism of e-voting is regulated carelessly. ${ }^{18} \mathrm{E}$-voting should be structured previously by pre-research involving technology and public policy experts. Specific and technical regulations must be prepared comprehensively to accommodate all parties, especially people with disabilities. Organizers and Governments must also be able to prepare super sophisticated infrastructure in guarding the selection process from cyber attacks, both from Indonesia or other entities.

\section{B. Research Method}

This research is a normative research method. The data used in this study are secondary data derived from laws and regulations such as the Law on Elections, Law on ITE, Government Regulations on One Data Indonesian, and Bill of Personal Data Protection Law, and legal literature in the form of journals, book, literature, internet and news related to this research. The data obtained in this study will be analyzed and delivered using descriptive-analytical methods.

\section{Discussion and Analysis}

\section{E-Voting Concept and Strategy in Indonesia Based on Law No.72017/ on General Election}

As stated in Law No. 7/ 2017 on General Elections, election activities in Indonesia as a democratic rule of law must be carried out with the principles of direct, public, free, confidential, truthful, and fair

17 https: / / tulungagung.bawaslu.go.id/opini-mungkinkah-pilkada-dengan-evoting/.

18 R. Michael Alvarez, Gabriel Katz \& Julia Pomares, “The Impact of New Technologies on Voter Confidence in Latin America: Evidence from E-Voting Experiments in Argentina and Colombia”, Journal of Information Technology \& Politics, 8:2, 2011, 199-217, DOI: 10.1080/19331681.2011.559739. 
elections. ${ }^{19}$ The discussion on e-voting has been mentioned in the discussion of Law Number $7 / 2017$ on General Elections, but this discourse was not continued due to various considerations. ${ }^{20}$ If this is realized, the application of e-voting can provide many benefits in the holding of elections in Indonesia. ${ }^{21}$ Using an electronic identity card or E-KTP can do reducing the risk of voting. In Estonia and Austria, the use of electronic identity cards is considered better than others in terms of security. ${ }^{22}$

E-KTP itself is a government program to document the community's population which is integrated into one card. ${ }^{23} \mathrm{E}-\mathrm{KTP}$ ownership can only be owned by one Indonesian citizen if they are over 17 years old. E-KTP itself has a lifetime validity period. The use of E-KTP as a medium for voter data verification can be applied in general elections organized in Indonesia. This verification is expected to be able to answer the problem regarding the determination of the permanent voter list which recurs every year. ${ }^{24}$ In Article 198 of Law No. 7/2017 on General Elections, every Indonesian citizen who is

19 Sulastri, Leni Natalia Zulita, "E-Voting Pemilihan Walikota Bengkulu Di Komisi Pemilihan Umum (KPU) Kota Bengkulu" (E-Voting of the Election of Bengkulu's Mayor in General Election Commission of Bengkulu), Jurnal Media Infotama, Vol. 11, No. 2, 2015, p. 182.

20 Siti Chaerani Dewanti, "Wacana Penggunaan E-Voting Pada Pemilu" (Discourse on the Use of E-Voting in General Elections), Info Singkat, Vol. XI, No.10, 2019, p. 26.

21 Manon de Vries and WouterBokslag, "Evaluating E-voting: Theory and Practice", Department of the Information Security Technology Technical University of Eindhoven, 2019,p. 3.

22 Jurlind Budurushi, Stephan Neumann and Melanie Volkamer, "Smart Cards in Electronic Voting Lessons learned from applications in legally binding elections and approaches proposed in scientific papers", This work has been published in Lecture Notes in Informatics (LNI), Volume P-205, 5th International Conference on Electronic Voting (EVOTE'12), p. 2.

23 https:// www.bp.t.go.id/profil/sejarah/848-e-ktp-identitas-pendudukyang-unik-dan-otentik.

24 Agus Qomaruddin Munir, Evrita Lusiana Utari, "Pemanfaatan E-KTP Untuk Proses Pemungutan Suara Pemilihan Umum Di Indonesia Menggunakan Sistem E-Vote" (The Use of E-KTP for the Process of Election's Voting in Indonesia Using E-Vote System), presented in the National Seminar on Technology, Information and Multimedia 2016 STMIK AMIKOM Yogyakarta, 6-7 Februari 2016, p. 2.4-1. 
17 years or older has been married, or has ever married has the right to vote on the election day. ${ }^{25}$ Affirmed in Article 348 paragraph (1) point c of Law No. 7/2017 on General Elections, the E-KTP holder according to his legal policy has the right to vote in general elections even though it is not registered in the permanent and additional voter lists. ${ }^{26}$

Mahfud MD stated that legal politics is a legal policy that contains the law in making new laws or replacing old laws in order to achieve the goals of the state as outlined in the 1945 Constitution. ${ }^{27}$ Election objectives regulated in Article 4 of Law No. 7 / 2017 on General Elections, namely, strengthen the democratic constitutional system, realize a fair and integrity election, ensure consistency in the regulation of the electoral system, provide legal certainty and prevent duplication of election arrangements, and realize effective and efficient elections. ${ }^{28}$ If you look at the objectives of the election as stipulated in the article above, you will find the fact that the use of evoting does not violate the rules in the law, even with the existence of e-voting can help realize the objectives of the election management arrangements as this regulation.

One of the issues raised in the implementation of e-voting in general elections is the provision of the method of voting stipulated in Article 353 of Law No. 7/2017 on General Elections, carried out by voting on ballots. ${ }^{29}$ Voting in general elections conducted through the e-voting mechanism is not done through voting on ballots, but the use of ballots is replaced by touch screen technology or other variations. ${ }^{30}$ Application to vote in elections through e-voting mechanism, which is contrary to regulations have happened before, pre-

25 Article 198 Law No. 7 / 2017 on General Elections.

26 Article 348 Section (1) Point c Law No. 7/2017 on General Elections.

27 Frenki, "Politik Hukum Dan Perannya Dalam Pembangunan Hukum Di Indonesia Pasca Reformasi" (Legal Politic and Its Role in the Development of Law in Indonesia Post-Reform), Asas Jurnal Hukum Ekonomi Syariah, Vol. 3, No. 2, 2011, p. 2.

28 Article 4 Law No. $7 / 2017$ on General Elections.

29 Article 353 Law No. 7 / 2017 on General Elections.

30 Sulastri, Leni Natalia Zulita, Op. Cit., p. 182. 
cisely in Article 88 of Law No. 32 / 2004 on Regional Government.

The Jembrana Regency Government conducted a judicial review of Article 88 of Law No. 32/2004 on the Regional Government to the Constitutional Court, as a negative legislator. In its decision, the Constitutional Court ruled that the word "vote" can also be interpreted using the e-voting method with the cumulative condition that it does not violate the principle of direct, public, free, confidential, truthful, and fair. Also, there has been readiness from the organizers in the area concerned both in terms of financing, technology, human resources and software. ${ }^{31}$ Based on this decision, Article 353 of Law No. 7 / 2017 on Elections in the use of e-voting systems in Indonesia's general elections is no longer a matter of juridical aspects.

Polling Place is the location of the voting by the owner of the vote $^{32}$ In its application, e-voting is carried out under the observation of officials, and the voting process is carried out centrally. What distinguishes between conventional systems and e-voting is the application of technology in the process. The differences include the voting process that is done using electronic direct-recording or electronic voting machines with a touch screen. ${ }^{33}$ If it is linked between the implementation of e-voting as above, it can be said that the application of e-voting can be justified following Article 1 Point 25 of Law No. 7/2017 on General Elections.

To use e-voting, it is also necessary to pay attention to the provisions Article 85 of Law No. 10/2016 on Regional Government, states that it is necessary to consider the readiness of infrastructure to create security and accountability and to pay attention to the readiness of the community based on the principle of secure and efficient. ${ }^{34}$ Therefore, the government must conduct a study in advance about the readiness of each region in terms of the readiness of

31 Constitutional Court's Decision Number 147/PUU-VII/2009.

32 Article 1 Point 25 Law No. 7/2017 on General Elections.

33 Okediran Oladotun O., Omidiora Elijah O., Olabiyisi Stephen O., Ganiyu Rafiu A., Sijuade Adeyemi A., "Towards Remote Electronic Voting Systems", Vol. 2, No. 4, 2011, p. 74

34 https: / t tulungagung.bawaslu.go.id/ opini-mungkinkah-pilkada-dengan-evoting/. 
the community and other supporting infrastructure. The economicgeographic principles approach can be used as an essential component in determining the territorial economic life of communities. ${ }^{35}$ This is intended so that the implementation of e-voting can be carried out effectively and under applicable regulations.

Based on the economic-geographic principles approach, regions that are proposed to be able to apply e-voting-based elections, it is necessary to provide instruments for voting, where these instruments can only be applied in certain areas. ${ }^{36}$ The procurement of such tools is basically a complement to the strategy for avoiding parties wishing to use their voting rights double. For conditional regions that have not been able to implement the e-voting system, verification data will be used an E-KTP scanned and adjusted to the voter data registered at the TPS (Polling Station/Voting Booth) or returns to the conventional strategy. Representative case shows; Geneva build successfully e voting by fulfilling, first; the great influences from Chancellor to make its policy run and it implemented with high technology and cyber security. Secondly, Geneva had experience to do great staircase and interactive simulation. Lastly, Geneva gives the role for the multidisciplinary expert to build, practice, evaluate, supervision and enforcement. ${ }^{37}$ Estonia in 2005 had minimized the time process of the election. Conventional election is required around 44 minutes, while e voting needs 6 minutes to finish. ${ }^{38}$ Comprehensively, Estonia has some significant requirements concerning the e-voting process; (i) Cyber security and executive power. (ii) Authorization documents of citizens which are integrated by election systems. (iii) Facilities

35 G.K. Kovalchuk, V.K. Lebedieva, L.M. Savchuk, L.M. Bandorina, "Economic, geographical aspects of the development of the regions of Ukraine", Journ.Geol.Geography.Geoecology, Vol. 28, No. 1, 2019, p. 88.

36 https://www.bphn.go.id/data/documents/p.hn_bid_informasi_dan_ teknologi.pdf.

37 Chevallier M, Warynski M and Sandoz A (2006) "Success Factors of Geneva's e-Voting System", The Electronic Journal of e-Government, Volume 4, Issue 2, p. 55 - 62, available online at www.ejeg.com.

38 Anna-Greta Tsahkna, "E-voting: Lesson from Estonia", Journal European View, Vol. 12, No.1, 2013, 59-66, https:// doi.org/10.1007\%2Fs12290-0130261-7. 
and human resources. (iv) Healthy political culture. ${ }^{39}$ However, some countries still have difficulties to perform e voting. New Zealand has been distressed to complete the e voting process because of cyber security and data validity. ${ }^{40}$

The urgency of the adoption of e-voting includes the associated threats confidentiality and security. Moreover, the next question is how far e voting could be decreasing the number of abstentions (passive non-voters) in the general election. This condition is particularly relevant as a number of cases in various countries which have performed e voting had not significantly increased active voters. Consequently, the importance of human resources, facilities, good faith and understanding from all the parties should be priorities before adopting e voting itself. Regardless of various models related to the implementation of e voting systems, it is very beneficial to understand the advantages and disadvantages of each system.

Accompanying with the e voting system that has been held in Jembrana Regency, the implementation of e voting was running by a single identity number method. It used an existing electronic residence card (eKTP) which was equipped with a chip and National Identification Number. Consequently voters have to hold eKTP to appoint the potential leaders. The first steps are resident with their eKTP will be verified by the committee and finally become the Permanent Voter List (DPT). Next, on election day, residents will come to the verification terminal for identical data from the machine. Voters who have registered in DPT will appear as identification number, name and photo. Hence, the voters go to the close voting booth, and choose the candidates on monitor. The final result of the selection of candidates is in the form of a print out, and committee will save the result.

39 Daniel de Kadt, "Voting Then, Voting Now: The Long-Term Consequences of Participation in South Africa's First Democratic Election", Journal of Politics, Vol. 79, No.2, 2283-2292, https:/ / doi.org/10.1086/690065.

40 Cheyne, Christine. "E-voting eventually? Online voting in (local) elections", Policy Quarterly, [S.1.], v. 12, n. 4, 2016. https://ojs.victoria.ac.nz/pq/article/view/463. 


\section{E-Voting Safety Strategy in Indonesia Based on the Law of ITE}

The application of elections in a democratic country is an essential and vital thing to elect a leader in that country. The traditional application of elections in developing countries is a challenge due to widespread security breaches and damaging democracy. ${ }^{41}$ The application of e-voting is also hazardous for violations that disrupt the public interest. One potential violation of the application of e-voting is the manipulation of election results. ${ }^{42}$ The social, technical, political, legal and economic aspects are both a challenge and a potential violation of the application of e-voting. ${ }^{43}$ In article 40 of Law No. 19/2016 on Amendments to Law No. 11/ 2008 on Information and Electronic Transactions (ITE), it is said that concerning public interests that are disturbed due to misuse of electronic information and electronic transactions, the government must protect it by statutory provisions. $^{44}$

Basically, we already have some methods to implement the electronic voting system. First methods focus on scanning systems and conventional systems. Voters will get a paper then the results are recorded and counted electronically. However, these procedures are complicated enough and need efforts as big as conventional systems. Additionally, calculation error by the scanner and electrical input should be considered. Next, voters can use direct recording electronics. The methods ask the voters to deliver their nominate via a computer or screen. Hence the voting results are stored in memory and could be transmitted either over the network to the national vote counting center. Finally, the internet voting system; it brings a flex-

41 John Sunday Ojo, Godwin Ihemeje, "Designing E-Voting As An 'Ap.aratus' For Combating Election Rigging: A Nigerian Model", Journal of Social and Political Sciences, Vol. 2, No. 3, 2019, p. 582.

42 https:/ / www.idea.int/sites/default/files/publications/introducing-electronic-voting-ID.pdf.

43 Mourine Achieng and Ephias Ruhode, "The Adoption and Challenges of Electronic Voting Technologies Within The South African Context”, International Journal of Managing Information Technology (IJMIT), Vol. 5, No. 4, 2013, p. 4.

44 Article 40 Law No.19/2016 on Information and Electronic Transactions. 
ibility for voters to give their choices for anywhere by internet devices. The result is sent to the polling station and recorded centrally. The most important from these methods are human resources, facilities and cyber security.

Disturbed public interests in elections not only occur because of the electoral system but also because of the aspects of user organizations. ${ }^{45}$ In general, disruptions that occur can be grouped into two. Attacks on digital assets is a type of attack aimed at changing the digital assets of an organization, where the source of the attack can occur from within or outside. The organizational and security settings provided by digital systems will determine the potential for attacks. Attacks on other types of assets are attacks that can be carried out both from outside and inside the environment or a combination of both, where the potential for attack will be determined only from organizational arrangements. ${ }^{46}$ Several features are the advantages of e-voting compared to conventional systems, among others, voting, correction, and verification of individual votes. This can be used as a solution to preventing fraud in elections. ${ }^{47}$ One solution to prevent the sale of votes is through end-to-end procedures because they are considered to guarantee security. ${ }^{48}$

This procedure is a method that allows voters to verify that a receipt has not changed their votes. And after the vote, the voice owners can double-check whether the votes he has given have been inputted in the data or not. ${ }^{49}$ End-to-end security procedures in their

45 Manik Hapsara, Ahmed Imran, and Timothy Turner, E-Voting in Developing Countries Current Landscape and Future Research Agenda, Springer International Publishing AG, 2017, p. 38.

46 https:/ / static.usenix.org/event/evt08/tech/full_papers/weldemariam/ weldemariam.pdf.

47 Riza Aditya, Byoungcheon Lee, Colin Boyd and Ed Dawson, "Implementation Issues In Secure E-Voting Schemes", Information Security Research Centre, Queensland University of Technology, 2004.

48 Nafise Mohammadi Shakiba, Mohammad-Ali Doostari, Mostafa Mohammad Pourfard, "ESIV: an end-to-end secure internet voting system", Springer, 2016, p. 1.

49 E-voting handbook" Council of Europe Publishing, https: / www.coe.int/t/ dgap/goodgovernance/ Activities / E-voting/E-voting\%202010/Biennial_ Nov_meeting/ID10322\%20GBR\%206948\%20Evoting\%20handbook\%20 
implementation will depend on the protocol and mechanism of the connection endpoints. Secure identity, protocol, algorithm, implementation and operation are part of the security requirements of endpoints. ${ }^{50}$ Therefore this procedure needs to be managed by the KPU (General Election Commission) to vote in the election.

Data management by the government in Indonesia is based on the Republic of Indonesia Presidential Regulation Number 39/2011 on One Data Indonesia, in its program, the government wants to make data that meets standards, metadata, data interoperability and uses reference codes and master data to produce accurate, integrated data, up-to-date, accountable and easily accessible for sharing between central and regional agencies. ${ }^{51}$ This regulation was made due to the frequent overlap of data between the central and regional governments, due to the absence of data synchronization. ${ }^{52}$ In elections, data overlaps often occur so that there are often multiple voters. ${ }^{53}$ The overlapping of multiple voters will be overcome by the synchronization of One Data Portal Indonesia. The relevant Ministries will hold one Data Portal Indonesia. ${ }^{54}$ For each controller of personal data must be able to guarantee and protect data security from data owners as stipulated in the Bill of Personal Data Protection Law, ${ }^{55}$ because the guarantee and protection of personal data security is part of human rights. ${ }^{56}$

A5\%20HD.pdf.

50 Eko Sakti Pramukantoro, Fariz Andri Bakhtiar, Ahmad Lutfi Bayu Aji, Deny Hari Prasetya Dewa, "Implementasi Mekanisme End-To-End Security pada IoT Middleware" (The Implementation of End-to-End Mechanism in IoT Middleware), JTIIK, Vol. 6, No. 3, 2019, p. 336.

51 Presidential Regulation of the Republic of Indonesia No. 39/2019 on Indonesia's One Data.

52 https://www.antaranews.com/berita/974048/perpres-satu-data-indonesia-pangkas-tumpang-tindih-data.

53 https: / / nasional.kompas.com/read/2018/09/12/13082951/daftar-pemilih-ganda-masalah-yang-itu-itu-melulu-dalam-pemilu?page $=$ all .

54 Article 36 Presidential Regulation of the Republic of Indonesia No. 39/2019 on Indonesia’s One Data.

55 Article 29 Bill of Personal Data Protection Law.

56 Sinta Dewi, "Konsep Perlindungan Hukum atas Privasi dan Data Pribadi Dikaitkan dengan Penggunaan Cloud Computing di Indonesia” (The Con- 
To maintain data security, there is a need for coordination regarding the management of the One Data Portal Indonesia. If referring to the function of the One Data Forum which is a forum communication and coordination of Central Agencies and/or Regional Agencies in the administration of One Data Indonesia, the Ministry of Communication and Information are valued to have the authority for this matter. This is because one of the functions of the Ministry of Communication and Information is to carry outpost and information technology, information technology application management, and management of information and public communication. ${ }^{57}$

\section{Conclusion}

Elections have been held using e-voting in several countries. In Indonesia, the use of e-voting has been carried out, one of which is in Jembrana Regency for the election of 54 villages, this election has received the legality of the Constitutional Court. In the 2024 election, it is predicted that e-voting can be applied in elections in Indonesia. If referring to the Law on General Elections concerning TPS and the voting mechanism that will be substituted by touch screen feature, there is no problem in the use of e-voting. If clashed with security issues, the application of end-to-end procedures can be utilized because it can guarantee data security. Likewise, for issues concerning personal data, it is necessary to pay attention by referring to related regulations such as the Law on ITE, Government Regulations on the Indonesian Data One, and the Bill on Personal Data Protection Law. Through the result of the Constitution Court, there are new election methods that are considered to be efficient, effective, low cost, energy and time. Thus, it is hoped that e voting can bring Indonesia towards e democracy. However, for those areas that have not been ready with the facilities, geographically problems and human resources, elections could be conventional elections with no violation of the principles; free, restricted, honest and fair.

cept of Legal Protection on Privacy and Personal Data in Relation to the Use of Cloud Computing in Indonesia), Yustisia. Vol.5, No.1, 2016, p. 22. 57 https://kominfo.go.id/tugas-dan-fungsi. 


\section{Bibliography}

\section{Regulations}

Law No. 19/2016 on the Amendments of Law No. 11/2008 on Information and Electronic Transactions.

Constitutional Court's Decision No. 147 / PUU-VII / 2009.

Law No. 7/2017 on General Elections.

Presidential Regulation of the Republic of Indonesia No. 39/2011 on Indonesia's One Data.

Bill of Personal Data Protection Law.

\section{Books}

M.D, Moh. Mahfud, Hukum dan Pilar-Pilar Demokrasi (Law and the Pillars of Democracy). Yogyakarta, Gama Media Offset, 1999. Surbakti, Ramlan, Sistem Pemilu di Indonesia: Antara Proporsional dan Mayoritarian (The Election System in Indonesia: Between Proportional and Majoritarian), Jakarta, P3DI Setjen DPR Republik Indonesia dan Azza Grafika, 2015.

\section{Journals and Seminars}

Achieng, Mourine and Ruhode, Ephias, "The Adoption And Challenges Of Electronic Voting Technologies Within The South African Context", International Journal of Managing Information Technology (IJMIT), 5(4), 2013.

Aditya, Riza, Lee, Byung Cheon, Boyd, Colin, and Dawson, Ed, "Implementation Issues In Secure E-Voting Schemes", Information Security Research Centre, Queensland University of Technology, 2004.

Anistiawati, Made Leita, "Implementasi Kebijakan Penerapan Elektronik Voting (E-Voting) dalam Pemilihan Kepala Desa (Studi Kasus :Pemilihan Kepala Desa di Desa Mendoyo Dangin Tukad, Kecamatan Mendoyo, Kabupaten Jembrana))'(Implementation of the Policy on Electronic Voting (E-Voting) in the Eelection of Head of Village (Case Study: the Election of Head of Village in Mendoyo Dangin Tukad Village, Mendoyo Subdistrict, Jem- 
brana District)), Jurnal Ilmu Administrasi Negara, 1(2), 2014.

Budurushi, Jurlind, Neumann, Stephan, Volkamer, Melanie "Smart

Cards in Electronic Voting Lessons learned from applications in legally binding elections and approaches proposed in scientific papers", This work has been published in Lecture Notes in Informatics (LNI), Volume P-205, 5th International Conference on Electronic Voting (EVOTE’12).

Dewanti, Siti Chaerani "Wacana Penggunaan E-Voting Pada Pemilu" (Discourse on the Use of E-Voting in General Elections), Info Singkat, XI(10), 2019.

Frenki, "Politik Hukum dan Perannya dalam Pembangunan Hukum di Indonesia Pasca Reformasi" (Legal Politics and Its Role in the Development of Law in Indonesia Podt-Reform), Asas Jurnal Hukum Ekonomi Syariah, 3(2), 2011.

Hapsara, Manik, Imran, Ahmed, and Turner, Timothy, E-Voting in Developing Countries Current Landscape and Future Research Agenda, Springer International Publishing AG, 2017.

Kovalchuk, G.K., Lebedieva, V.K., Savchuk, L.M., Bandorina, L.M., "Economic, geographical aspects of the development of the regions of Ukraine", Journ.Geol.Geography.Geoecology, 28(1), 2019.

Kumar, Sanjay, Walia, Ekta, "Analysis Of Electronic Voting System In Various Countries", International Journal on Computer Science and Engineering (IJCSE), 3(5), 2011.

Munir, Agus Qomaruddin, Utari, Evrita Lusiana, "Pemanfaatan EKTP Untuk Proses Pemungutan Suara Pemilihan Umum Di Indonesia Menggunakan Sistem E-Vote" (The Use of E-KTP for the Process of Election's Voting in Indonesia Using E-Vote System), presented in National Seminar on Technology, Information dan Multimedia 2016 STMIK AMIKOM Yogyakarta, 6-7 Februari 2016.

Muntoha, "Demokrasi dan Negara Hukum" (Democracy and the State of Law), Jurnal Hukum, 3(16), 2009.

O., Okediran Oladotun, O., Omidiora Elijah, O., Olabiyisi Stephen, A., Ganiyu Rafiu, A., Sijuade Adeyemi, “Towards Remote Electronic Voting Systems”, 2(4), 2011. 
Ojo, John Sunday, Ihemeje, Godwin, "Designing E-Voting As An 'Apparatus' For Combating Election Rigging: A Nigerian Model", Journal of Social and Political Sciences, 2(3), 2019.

Pramukantoro, Eko Sakti, Bakhtiar, Fariz Andri, Aji, Ahmad Lutfi Bayu, Dewa, Deny Hari Prasetya, "Implementasi Mekanisme End-To-End Security pada IoT Middleware" (The Implementation of End-to-End Mechanism in IoT Middleware), JTIIK, 6(3), 2019.

Sarbaini, "Demokratisasi Dan Kebebasan Memilih Warga Negara dalam Pemilihan Umum" (Democratisation and Citizen's Freedom to Vote in General Elections), Jurnal Inovatif, VIII(I), 2015.

Shakiba, Nafise Mohammadi, Doostari, Mohammad-Ali, Pourfard, Mostafa Mohammad, "ESIV: an end-to-end secure internet voting system”, Springer, 2016.

Sinta Dewi, "Konsep Perlindungan Hukum Atas Privasi dan Data Pribadi Dikaitkan dengan Penggunaan Cloud Computing di Indonesia" (The Concept of Legal Protection on Privacy and Personal Data in Relation to the Use of Cloud Computing in Indonesia), Yustisia, 5(1), 2016.

Sulastri, Leni Natalia Zulita, "E- Voting Pemilihan Walikota Bengkulu di Komisi Pemilihan Umum (KPU) Kota Bengkulu” (E-Voting of the Election of Bengkulu's Mayor in General Election Commission of Bengkulu), Jurnal Media Infotama, 11(2), 2015.

Vodovnik, Żiga, "Lost In Translation: The Original Meaning Of Democracy”, Teorija In Praksa, let. 54(1), 2017.

Vries, Manon de, and Bokslag, Wouter, "Evaluating e-voting: theory and practice", Department of Information Security Technology Technical University of Eindhoven, 2019.

Wojtasik, Waldemar, "Functions of Elections in Democratic Systems", Political Preferences, 4, 2013.

\section{Website}

https: / / kominfo.go.id/tugas-dan-fungsi.

https: / / nasional.kompas.com/read/2018/09/12/13082951/daf-

tar-pemilih-ganda-masalah-yang-itu-itu-melulu-dalam-pem- 
ilu?page $=$ all.

https: / / static.usenix.org/ event/ evt08/tech/full_papers/weldemariam/weldemariam.pdf.

https: / / tulungagung.bawaslu.go.id/ opini-mungkinkah-pilkada-dengan-e-voting/.

https: / / www.antaranews.com/berita/974048/ perpres-satu-dataindonesia-pangkas-tumpang-tindih-data.

https: / / www.bphn.go.id/data/documents/pphn_bid_informasi_ dan_teknologi.pdf.

https: / / www.bppt.go.id/profil/ sejarah/ 848-e-ktp-identitas-penduduk-yang-unik-dan-otentik.

https: / / www.bppt.go.id/ teknologi-informasi-energi-danmaterial/ 1745-e-voting-pilkades-jembrana-sebuah-miniaturpemilukada.

https: / / www.cnnindonesia.com/internasional/20161108135120-

134-171169/pemilu-as-pakai-mesin-canggih-sulit-dicurangi.

https: / / www.coe.int/t/dgap/goodgovernance/Activities/

E-voting/E-voting\%202010/Biennial_Nov_meeting/ ID 10322\%20GBR\%206948\%20Evoting\%20handbook\%20 A5\%20HD.pdf.

https: / / www.idea.int/ sites / default/files / publications / introducingelectronic-voting-ID.pdf.

https: / /www.republika.co.id/berita/nasional/politik/19/05/09/ pr7jdk428-menkominfo-evoting-bisa-diterapkan-pada-pilkada2024. 